\title{
Theoretical And Methodological Fundamentals Of Administrative And Legal Regulation Of Mediation
}

\author{
Kseniia Tokarieva, PhD in Law, Associate Professor of Constitutional and Administrative Law, National \\ Aviation University, 03058, Ukraine, Kiev, Liubomyra Huzara ave., https://orcid.org/0000-0001-5705-5211, \\ ph.d.tokareva@gmail.com
}

\begin{abstract}
The article is devoted to the study of theoretical and methodological foundations of mediation, which determine the content of its administrative and legal regulation. Scientific views on the essence of the mediation procedure from the point of view of organizational, communication, psychological approaches are considered, the conceptual apparatus of mediation is generalized. Thus, mediation should be considered as an alternative way to resolve the dispute, where the conflicting parties on the basis of voluntary expression use the help of a neutral, impartial and independent third party - a mediator who directs the parties to jointly resolve the dispute by using his special knowledge, skills and experience in the process. The understanding of mediation by domestic scholars in administrative law is analyzed. Obstacles to the absolute use of mediation to resolve public law disputes in Ukraine have been identified. The challenges facing the introduction of a peaceful settlement of administrative disputes with the participation of a mediator are the special attitude of Ukrainians to the subjects of power; corruption risks; disinterest of public authorities in changes in their activities; issues of initiative and voluntariness of the procedure; debatability of mediation of certain categories of disputes; lack of legal regulation of mediation. A generalized list of characteristic features of the mediation procedure is offered. The main functions and special principles of mediation in the administrative process are determined, which in the future may form the basis of its administrative and legal regulation. Further research on the issues of the scientific article should be aimed at studying the content of administrative and legal regulation of mediation and regulatory and theoretical foundations for determining the directions of building effective administrative and legal regulation of mediation in Ukraine.
\end{abstract}

Keywords: alternative dispute resolution, mediation, administrative process, administrative and legal regulation, public law disputes, mediator, subject of power.

Received: 09.12.2020 $\quad$ Accepted: 14.01.2021 $\quad$ Published: 05.02.2021

\section{INTRODUCTION}

The processes of globalization and the rapid development of society lead to the complication of social relations and the emergence of new regulatory tools for such relations. Relatively new means of social influence are alternative ways of resolving disputes. As the number of social conflicts increases, there is a need to resolve them immediately, and the traditional judicial system is not always able to meet the needs of society. One of such institutions of out-of-court dispute resolution is mediation, which is designed to effectively and quickly, while saving the parties, to help the parties to the disputed relationship to reach an independent optimal dispute resolution. The Socio-Legal Institute of Mediation is recognized by the international community as an effective tool for resolving disputes, conflicts and disputes in the field of private law and is widely used in the European Union and the United States. Recently, scholars around the world have drawn attention to the possibility of using mediation in disputes in the field of public law, which not only helps to optimize the work of judges, but also improves relations between the state and the citizen as a whole, instilling confidence in the latter. The above testifies to the relevance of the topic of the scientific article, its important theoretical and practical significance for the further development of administrative and legal regulation of mediation.

\section{Formulation of the problem}

Since there are mediation organizations in our country that carry out activities in the field of mediation, we can say that there is a demand in society for alternative dispute resolution. Despite the successful foreign experience of using mediation in disputes, where one of the parties is a subject of power, and numerous pilot projects for its implementation, Ukraine has not yet formed legislation on mediation, the main directions of alternative ways of resolving public disputes have not been identified. And there is a low level of awareness about the possibility of using such tools among the population. 


\section{The purpose of the article}

The aim of the article is to study the theoretical foundations of mediation, which in the future can be used to form the administrative and legal regulation of this method of alternative dispute resolution. The goal is to perform the following tasks: research of the conceptual apparatus and the formation of their own definition of mediation; analysis of the possibility of using the mediation procedure in certain categories of disputes; determination of the main features and functions of the legal institution of mediation; study of the basic principles of mediation.

\section{Objects and subjects of research}

The objects of research are the theoretical and methodological foundations of administrative and legal regulation of mediation. The subjects of the research are the definitions of mediation in legal doctrine, ability to mediate the public-law disputes, characteristics, main directions of legal influence and principles of mediation.

\section{Research methods}

The methodological basis of the study is a set of general scientific and special legal methods of cognition. Comparative-critical analysis of the concepts of understanding mediation in a broad and narrow sense allowed to identify the main aspects of the concept and offer their own definition. The dogmatic method allowed to analyze the content of the main categories that form mediation, in particular features, functions and principles. Methods of system analysis and grouping are used to classify the fundamental principles and main directions of the legal impact of mediation. Methods of cognition (methods of analysis and synthesis) were used, which provided an opportunity to determine the main theoretical foundations for the further creation of administrative and legal regulation of the mediation procedure. The theoretical basis of the study are the scientific works of leading domestic and foreign scholars in the field of mediation and pre-trial settlement of administrative disputes.

\section{RESULTS AND DISCUSSION}

\section{FIRST TOPIC: CONCEPTUAL AND CATEGORY APPARATUS OF MEDIATION.}

Among the main forms of dispute resolution (forms of dispute resolution) in the literature are most common: proceedings in state courts; arbitration; alternative dispute resolution (Alternative Dispute Resolution); online dispute resolution (Yermakova E., 2016, p. 55). Although alternative dispute resolution is non-state in nature, such dispute resolution methods do not preclude recourse to traditional state dispute resolution institutions. In view of the above, alternative dispute resolution is a form and process that provides a set of universal, flexible, agreed by the parties, methods, means and techniques of resolving legal conflicts without recourse to the procedure of state litigation.

Almost two thirds of respondents consider state regulation to be insufficiently effective (30.0\%) or almost invisible to their own family (26.3\%) (Dragan I., Kovalova O., Gryshchenko I., Ridei N., Livinskyi A., 2020, pp. 6639). The European Society recommends that states use alternative dispute resolution, one of which is mediation, as an alternative to administrative litigation. In Recommendation Rec (2001) 9 on alternatives to litigation between administrative authorities and private parties, adopted by the Committee of Ministers of the Council of Europe on 5 September 2001on alternatives to litigation between administrative authorities and private parties was determined that the constant increase in the number of disputes weakens administrative courts, and the use of out-of-court dispute resolution will help bring administrative bodies closer to the public. As there is no legal regulation of mediation in Ukraine, it is advisable to study the conceptual apparatus of such an alternative way of resolving disputes. In particular, according to B.G. Rysay $(2017$, p. 314), mediation in a broad sense is the desire of society to overcome socio-cultural contradictions in accordance with the needs of development. Whereas S. I. Zapara (2015, p. 83) identifies it with the external motivation of the parties to reconcile, which, in our opinion, rather superficially describes the institution of dispute resolution with the participation of a mediator. The most common among scholars is a narrow understanding of mediation in terms of organizational approach. Proponents of this approach view the mediation procedure as the settlement of a dispute with the assistance of a mediator based on the voluntary consent of the parties in order to reach a mutually acceptable solution (Dumas A., 2018, p. 30).

The opinion of the Australian mediator G. Rooney (2020) is worth to note, who defines mediation as a complex adaptive system based on the complex interaction of the participants in the process. According to the author, the results of mediation are impossible to predict, so, in essence, mediation is a process of discovery in which the mediator can allow the fixed positions of the parties to combine into something new and unexpected.

We agree with the opinion of Bashmakova N. I., Ryzhova N. I., and Kuznetsova O. A. (2015, p. 169), who emphasize the integrative nature of mediation. Representatives of the communicative 
approach P. Carnevale and D. Prut (1992, p. 532) call mediation a kind of negotiation, where a third party helps the parties in the discussion. The same view is shared by other scholars, who understand mediation as a process of negotiation involving a neutral third party, which is only interested in the parties resolving the dispute as favorably as possible for themselves (Allakhverdova 0., 2006, p. 31); a method of resolving a dispute on the basis of negotiations with the help of a neutral mediator who has no decision-making power (Lennoir N., 2004, p. 9). Instead, we consider the remarks of J. Berkovich and R. Jackson (2001, p. 60 ) to be appropriate, which stipulate that mediation should not be equated with negotiation, as the procedure has additional resources and enhanced connections and communication opportunities arising from conflict management.

Considering mediation from the standpoint of psychology and conflict studies, the mediation procedure is interpreted as: communication burdened with negative emotions of conflicting participants, aimed at successful conflict resolution (Kulikova L. \& Prokhorova 0., 2016, pp. 100-101); a set of reflective technologies of conflict negotiations, where conflicting parties with the help of an independent mediator independently reflect contradictions, make decisions and create agreements, resolving the conflict (Pokhmelkina G. \& Semenov I., 2008, p. 123); socio-psychological phenomenon, the essence of which is to create psychological conditions that lead to a decrease in emotional stress, constructive decisions and conflict resolution (Allakhverdova 0., 2007, p. 151).

Thus, mediation - is an alternative way of resolving a dispute, where the conflicting parties on the basis of voluntary expression use the help of a neutral, impartial and independent third party - a mediator who directs the parties to jointly resolve the dispute with special legislation knowledge, skills and experience.

\section{SECOND TOPIC: MEDIABILITY OF PUBLIC LEGAL DISPUTES IN UKRAINE}

The experience of using alternative dispute resolution, as rightly noted by Yakovlev V. F. (2016, p. 16), proves that first mediation was used to resolve disputes in the field of private law, then - collective labor disputes, and then disputes that are traditionally resolved in administrative justice - between a citizen and the state. Krytska M. S. (2016, p. 178) proposes to define administrative mediation as a way to resolve disputes between the state and society that arise in connection with the implementation of state activities, with the assistance of a mediator on the basis of voluntary agreement of the parties to achieve mutually acceptable decision.

Based on the general concept of mediation, we can define mediation in the administrative process as an alternative way of resolving a public dispute, where the parties use such assistance of a neutral, impartial and independent mediator, which directs the parties to a joint optimal dispute resolution.

For the post-Soviet countries, mediation in public law disputes raises many doubts and reservations, as the prevailing opinion in society is about the unconditional authority of public authorities. The country's ability to provide a set of measures to increase security is important to ensure economic stability. (Gryshova, I.; Kyzym, M.; Hubarieva, I.; Khaustova, V.; Livinskyi, A.; Koroshenko, M., 2020, p. 7692). For example, Kivalov S. V. (2014, p. 15) believes that the use of mediation in administrative proceedings will be effective only in a state governed by the rule of law, and the direct borrowing of foreign experience in Ukraine will not work. In contrast, there is a position that mediation provides the parties with a partnership and the opportunity to work together in the areas of social security, economics, finance and public law (Bashmakova N., Ryzhova N. \& Kuznetcova 0., 2015, p. 160).

Mediation in administrative disputes has a number of advantages, such as increased control of the parties over the resolution of the dispute; increasing the effectiveness of traditional administrative proceedings by reducing the number of court cases; improving relations and building trust between the authorities and citizens. Some scholars emphasize the need to raise awareness of mediation among civil servants, lawyers and judges and to include consensus in the list of legal responsibilities of public authorities. (De Graaf K. J., Marseille A. T., \& Tolsma H. D., 2014, P. 591 -594).

Regarding the study of obstacles to the introduction of mediation in public law disputes, Balukh V. S. (2013, p. 34) provides a list of deterrents to mediation in tax disputes: low interest of taxpayers associated with the expectation of dispute resolution through corruption; weak motivation of tax authorities to change the principles and methods of their activities; unwillingness of the parties to the dispute to fulfill their obligations as a result of an alternative dispute resolution. We can say that such obstacles apply not only to tax, but also to any dispute, where at least one of the parties is a subject of power.

Examining the Lithuanian model of mediation, E. Bilevičiūtè and V. Milius (2019, p. 133) emphasize that in the European Union administrative disputes concerning material and tax relations, civil 
service, management of financial assistance at the national level are considered as mediatable, which contributes to restoring social balance.

Instead, domestic experts emphasize the need to establish limits on the use of mediation in public law disputes. Muza O.V. (2011, p. 243) points out that the specifics of administrative and legal disputes require a separate approach. According to the author, mediation is impossible when appealing against acts, actions or omissions of the Parliament of Ukraine, the President of Ukraine, the Cabinet of Ministers of Ukraine and other official authorities, because the competence of these subjects of power cannot meet individual requirements of applicants in administrative proceedings. A similar opinion is shared by A. Lysko (2019), who considers unmediable disputes between the subjects of power over the exercise of their competence in the field of governance related to the electoral process or the referendum process.

However, Krasilovska Z. V. (2015, p. 203) does not agree with the impossibility of using mediation in election disputes, as the huge proportion of such disputes in Ukraine are appeals to clarify the lists, change the place of election address and place of voting. For example, in Indonesia, mediation in electoral disputes has become a traditional form of protection of violated voting rights of citizens (Lathif N., Insan I. H. \& Wijaya M. M., 2020, p. 658.).

\section{THIRD TOPIC: MAIN CHARACTERISTICS AND DIRECTIONS OF LEGAL INFLUENCE OF MEDIATION AS AN ADMINISTRATIVE AND LEGAL INSTITUTE}

The next element of the theoretical study of administrative and legal regulation of mediation is the features of mediation. H. Bessemer (2004, pp. 14-15) identified the technical features of mediation, such as the presence of an agent who acts as a mediator; the presence of all parties to the conflict; informal extrajudicial nature; voluntary participation in the procedure and self-determination in conflict resolution relations.

P. P. Shevchuk (2011, p. 234) calls the advantage of mediation in administrative disputes to bring the administration closer to society by avoiding antagonism between the parties to the dispute and thus providing more appropriate solutions in some types of disputes, which, in our opinion, can also be attributed to features of the procedure. While V. Kuzmyshyn (2009, p. 47), giving a description of mediation in administrative proceedings, highlights the obligation of the mediator to act in the interests of all participants of the process. In this case, in addition to legal aspects, such interests may be economic, personal and any individual interests. (Azer Dilanchiev, Gryshova Inna, Rogach Svetlana, Diachenko Oleksii, Batrakova Tetyana, Shabatura Tatyana., 2020)

The directions of the influence of mediation on public relations, which at the same time form the tasks of legal regulation, are expressed through the functions of the institution of mediation. The functions of mediation are derived in content from the functions of law, but are not identical with them. The functions of law are regulatory, protective, informational and preventive (Zamorska L., 2015, P. 6-7). We distinguish organizational, educational, integration, democratic and static functions of mediation. Gryshova, I.; Kofman, B.; Petrenko, O. (2019).

The organizational function of mediation in the administrative process can be considered in two aspects: the procedure is the coordination of the mediator process, the organization of negotiations and other stages of mediation; Mediation coordinates the interaction of individuals with public authorities, helps to increase public confidence in the state. The informative function is expressed through the activities of the judge, who informs the parties about the possibility of such a procedure, and the mediator, who can inform the parties about the possibility to turn to lawyers or experts on the subject of the dispute and others. In general, during the procedure from its beginning to the final stage, the mediator uses and operates with the information received from the parties to effectively resolve the dispute. The educational function of mediation in the administrative process is to form a certain legal awareness of citizens, according to which the dispute even with the subject of power can be resolved peacefully, out of court.

The integration function in theory is to unite people into certain social groups. In this context, it is worth mentioning the association of mediators who contribute to the development and improvement of the institution of mediation, including in administrative proceedings. The democratic function is related to the advantages of mediation as an alternative method of dispute resolution. Mediation is able to relieve administrative courts, reduce the cost of resolving disputes, which facilitates access to justice. The static function of mediation in the administrative process is to consolidate and stabilize the social relations associated with its application. The possibility of using mediation is popularized, enshrined in law and is a stable socio-legal institution for dispute resolution.

\section{FOURTH TOPIC: PRINCIPLES OF MEDIATION IN ADMINISTRATIVE LAW}


Administrative and legal regulation of any legal institution is based on the basic principles. Article 3 of the draft Law of Ukraine "About Mediation" № 3504 of 19 May 2020) stipulates that mediation is conducted by mutual consent of the parties to the process, taking into account the principles of voluntariness, confidentiality, independence and neutrality of the mediator, self-determination and equality of rights of the parties to mediation.

According to K. O. Shumova (2015, p. 16), the legal significance of the principles of mediation is divided into direct legal (voluntary mediation, equality of arms, dispositiveness, cooperation, confidentiality, limitation) and non-legal (good faith, impartiality and neutrality of mediator), tolerance, subsidiarity and freedom of the parties, etc.).

Quite common in the legal literature is the classification of the principles of mediation, derived from the principles of law: common law, intersectoral and specific legal principles (Prytyka Y., 2010, p. 91).

Regarding the basic principles of mediation in resolving administrative disputes, A. Lysko (2019) highlights the problem of implementing the principles of voluntariness and initiative, because the ability of civil servants to act on their own is limited. However, we agree with the position of Dr. Tetiana Tielkiniena, Gryshova Inna, Shabatura Tatyana, Nehodenko Viktoriia, Didur Hanna, Shevchenko Alisa.(2020), who argues that arising from the relationship of inequality and unequal position of the parties, administrative dispute as a protected legal relationship develops between equal subjects, and power in this case is absent. That is, an individual and a subject of power, being in a disputed relationship, have the same rights and obligations to form their positions and requirements and prove the circumstances of the dispute. ( Bilynska M, Baltsii Y, Boyarskyy O, Bykova T, Gryshova Rymma, 2020)

The principles of mediation in public law should be divided into general and special. The general principles, i.e. those inherent in the mediation procedure in any category of disputes, should be defined: voluntary participation of the parties; impartiality, neutrality and independence of the third party mediator; independence and equality of the parties; confidentiality of the procedure; flexibility and relatively low formality of the procedure; compliance of the agreement with the results of mediation to the law. In our opinion, the establishment of mandatory mediation is fully in line with the principle of voluntariness, as the party to the dispute may at any time refuse to conduct the procedure and resort to the traditional way of protecting their rights and interests - litigation.

Impartiality, neutrality and independence of the mediator is the absence of any personal interest of the mediator in the outcome of the dispute and commitment to one of the parties to the conflict; lack of influence of the mediator's subjective feelings on the course of dispute resolution; providing the parties with equal opportunities to express their own positions and provide organizational consultations, which is inextricably linked to the implementation of the principle of equality of participants in mediation. The principle of independence of the parties to mediation provides for the free choice of a mediator in accordance with their own preferences and the formation at its own discretion of the provisions of the agreement based on the results of mediation. The confidentiality of the mediation procedure consists in the non-disclosure by the participants of the information that became known to them during the dispute settlement process, without the prior consent of the other participants. The informality and flexibility of the procedure, as we mentioned earlier, is due to the lack of a strict procedure.

The principles of proportionality and initiative should be included in the special principles i.e. inherent mostly in mediation in public law disputes. Proportionality presupposes the observance of the balance of public and private interests during the procedure. Regarding the principle of initiative - we agree with the need to consolidate the powers of public authorities and local governments on the possibility of initiating or accepting a proposal for mediation.

\section{CONCLUSIONS}

Based on the above, we can form the concept of "mediation" - an alternative way to resolve the dispute, where the conflicting parties on the basis of voluntary expression use the help of a neutral, impartial and independent third party - a mediator who directs the parties to joint optimal dispute resolution by having special knowledge, skills and experience, complying with the requirements of the law. Mediation has become a response to social challenges and public dissatisfaction with the possibilities of exercising one's right to judicial protection. For a long time, countries around the world have improved the informal procedure for resolving disputes through the use of communication techniques, psychology and conflict studies. Therefore, mediation should be considered not only in terms of organizing the negotiation process, but also as a complex socio-legal institution that has emerged in accordance with the needs of society. As of today, the issue of creating legal regulation of mediation has become acute in Ukraine. Analyzing the scientific views of domestic experts, it becomes clear that the use of mediation in the private-legal sphere of relations is considered unconditional, while the resolution of public-law disputes 
through mediation is questionable. As for the problems that must be taken into account when creating administrative and legal regulation of dispute resolution with the participation of a mediator, they are a negative attitude and lack of public confidence in the authorities, high levels of corruption, lack of any legal enshrinement of mediation (including including the mechanism of enforcement of decisions and special powers of the subjects of power to participate in mediation).

Administrative and legal regulation of mediation should be based on the theoretical foundations of the institution. In particular, its specific features are the presence of disputes, voluntary principles, confidentiality, flexibility, focus on achieving the parties a optimal mutually beneficial and mutually acceptable solution (consensus) on the subject of the dispute, universality, the mediator's special knowledge, skills and abilities in public resolution. Areas of legal influence of the institution of mediation are its organizational, educational, static, integration and democratic functions. The principles of mediation in the administrative and legal space should be considered general principles - voluntariness; confidentiality; independence, neutrality and impartiality of the mediator; equality and independence of the parties to the procedure; legality of the agreement based on the results of mediation, and special the principle of balance of public and private interests; the principle of initiative. Resolution of public law disputes using mediation as an indicator of the rule of law in the state is necessary for Ukrainian society, as it helps reduce conflict, creates social norms of peaceful settlement of disputes and strengthens the relationship between state and citizen.

\section{REFERENCES}

Yermakova E. P. (2016). On the concept of forms and methods of dispute resolution in multi-system legal systems. Gaps in Russian legislation, (6), 55-58.

Dragan Ivan.O., Kovalova Olena, Gryshchenko Iryna, Ridei Nataliia, Livinskyi A. I. Assessment Of The Role Of The State As A Leader In The Demographic Development Of Ukraine. Solid State Technology Vol. 63 No. 6 (2020). Retrieved from: http://www.solidstatetechnology.us/index.php/ISST/article/view/4400

Recommendation Rec (2001) 9 of the Committee of Ministers to member states on alternatives to litigation between administrative authorities and private parties. Retrieved from: https://rm.coe.int/16805e2b59

Rysay B. G. (2017). Mediation as a form of resolving an administrative dispute. Scientific sheets of Belgorod State University. Series: Philosophy. Sociology. Law, (43 (2), 313-317.

Zapara S. I. (2015). The concept of mediation and features of its formation in Ukraine and the world. Comparative and Analytical Law, (3), 83-85.

Dumas A. (2018). Mediation in data matters. Kwartalnik Krajowej Szkoły Sądownictwa i Prokuratury, (4 (32)). 29-42.

G. Rooney (2020). Introduction a New Definition of Mediation. Kluwer Mediation Blog, Retrieved from: https://www.mediate.com/articles/rooney-definition-mediation.cfm

Bashmakova N. I., Ryzhova N. I. \& Kuznetsova O. A. (2015). Historical retrospective of mediation as an integrative concept: paradigms of study and interdisciplinarity. Management Consulting, (6 (78)), 159172.

Carnevale, P. J. \& Pruitt D. G. (1992). Negotiation and mediation. Annual review of psychology, 43 (1), 531-582.

Allahverdova O. V. (2006). Mediation is a new communicative practice in conflict resolution. Journal of Sociology and Social Anthropology, 9 (4), 31-49.

Lennoir N. N. (2004). Alternative dispute resolution: negotiations and mediation: teaching method. allowance. St. Petersburg: Publishing House of the St. Petersburg Institute of Law named after Prince PG Oldenburg.

Bercovitch J. \& Jackson R. (2001). Negotiation or mediation? An exploration of factors affecting the choice of conflict management in international conflict. Negotiation Journal, 17 (1), 59-77.

Kulikova L. V. \& Prokhorova O. A. (2016). Research approaches to the discourse of mediation in the focus of interdisciplinarity. Philological sciences. Questions of Theory and Practice, (2-2 (56)), 100-104.

Pokhmelkina G. F. \& Semenov I. N. (2008). Reflection technologies of mediation in modern foreign practical psychology and conflictology. Psychology. Journal of the Higher School of Economics, 5 (1), 121138.

Allahverdova O. V. (2007). Mediation as a socio-psychological phenomenon. Bulletin of St. Petersburg University. Series 6. Political Science. International Relations, (2-1), 151-158.

Yakovlev V. F. (2006). Law of free application. Mediation and law. Mediation and Reconciliation, (1), 1216.

Kritskaya M. S. (2016). Administrative mediation as a form of public control over police activities. Bulletin of Voronezh State University. Series: Law, (3), 177-183. 
Gryshova I., Kyzym M., Hubarieva I., Khaustova V., Livinskyi A., Koroshenko M. Assessment of the EU and Ukraine Economic Security and Its Influence on Their Sustainable Economic Development. Sustainability2020, 12, 7692.

Kivalov S. V. (2014). The essence and features of pre-trial settlement of administrative disputes. Scientific works of the National University "Odessa Law Academy", (14), 5-18.

De Graaf K. J., Marseille A. T. \& Tolsma H. D. (2014). Mediation in Administrative Proceedings: a comparative perspective. In Alternative Dispute Resolution in European Administrative Law (pp. 589605). Springer, Berlin, Heidelberg.

Balukh V. S. (2013). On the possibility of introducing mediation in Ukraine in resolving tax disputes. Law and Public Administration, (3), 31-35.

Bilevičiūtė E. \& Milius V. (2019). Non-judicial mediation in the Lithuanian administrative process: current issues. Administrative law and process, (4 (27)), 115-134.

Muza O. V. (2011). Some aspects of the use of mediation in the administrative proceedings of Ukraine. University Scientific Notes, (4), 239-244.

Lysko A. (2019). Problems of implementation and conduct of mediation in the administrative proceedings of Ukraine. Blog of the Lviv Mediation Center. Retrieved from: www.gromada.lviv.ua/analytic/587.

Krasilovska Z. V. (2015). Conditions for the use of mediation for the settlement of disputes with public authorities: domestic and foreign aspects. Theory and practice of public administration, (4), 200-207.

Lathif N., Insan I. H. \& Wijaya, M. M. (2020). Perspective on Settlement of General Election Disputes Through Mediation, Adjudication and Legal Efforts: Settlement of State Administrative Judicial Disputes. International Journal of Multicultural and Multireligious Understanding, 7 (5), 650-661.

Bessemer H. (2004). Mediation: Conflict mediation. (translated by German NV Malova) Kaluga: Spiritual knowledge.

Shevchuk P. P. (2011). Mediation in administrative disputes. Actual problems of humanities and natural sciences, (4), 240-246.

Kuzmishin V. (2009). Prospects for the implementation of the mediation procedure in administrative proceedings. Visn. Senior admin. Court of Ukraine, (3), 46-48.

Zamorska L. I. (2015). Functions of law: content-theoretical analysis. Current issues of domestic jurisprudence, (6), 3-9.

On mediation: Draft Law of Ukraine of May 19, 2020 № 3504 (2020). Parliament of Ukraine. Retrieved from: http://w1.c1.rada.gov.ua/pls/zweb2/webproc4 1?pf3511=68877

Shumova K. A. (2015). Principles of mediation (dissertation ... Candidate of Law). Saratov State Law Academy, Saratov, Russia.

Prytyka Y. D. (2010). Content and classification of mediation principles. Bulletin of the Ministry of Justice of Ukraine, (10), 86-92.

Sychova O. A. (2013). Possibilities of mediation in resolving administrative and legal disputes. Volga pedagogical search, (1), 131-136.

Bilynska M, Baltsii Yurii, Boyarskyy Oleksandr, Bykova Tetiana Valerijivna, Gryshova Rymma. Modern criteria for the effectiveness of the mayor as a leader in the local government system. Solid State Technology Vol.63 No. 5 (2020) p. $5844-5867$

Gryshova, I.; Kofman, B.; Petrenko, O. (2019). Migration cultures and their outcomes for national security, Journal of Security and Sustainability Issues 8(3): 530.https://doi.org/10.9770/jssi.2019.8.3(18)2q

Dr. Tetiana Tielkiniena, Gryshova Inna, Shabatura Tatyana, Nehodenko Viktoriia, Didur Hanna, Shevchenko Alisa. LOBBY LEGALIZATION - LEGAL INSTRUMENT FOR ENSURING STATE SUBSIDIES TO LEADERS OF AGRICULTURAL PRODUCERS . JCR. 2020; 7(4): 1679-1683. doi:10.31838/jcr,07.04.274

Azer Dilanchiev, Gryshova Inna, Rogach Svetlana, Diachenko Oleksii, Batrakova Tetyana, Shabatura Tatyana. REMITTANCE LEVELS AND ENTREPRENEURIAL ACTIVITY IN POSTSOVIET COUNTRIES . JCR. 2020; 7(4): 1655-1663. doi:10.31838/jer.07.04.271 